\title{
ANÁLISE DO PODER PREDITIVO DOS GENES ARD1A E NGX6 EM PACIENTES COM CÂNCER DE MAMA
}

\author{
Eliane Aline Ribeiro ${ }^{1}$ \\ Raissa Monteiro da Silva ${ }^{2}$ \\ Abaetê Leite Canto ${ }^{3}$ \\ Luis Henrique Ferreira de Moraes ${ }^{4}$ \\ Renata de Azevedo Canevari ${ }^{5}$
}

\begin{abstract}
Resumo: A identificação de marcadores moleculares poderá ser uma ferramenta adicional na seleção mais específica das pacientes onde a remoção dos linfonodos axilares é mais indicada. O objetivo é avaliar se os genes ARD1A e NGX6 são marcadores preditivos do envolvimento dos linfonodos axilares no câncer de mama. Foi realizada a análise de expressão gênica pela técnica de RT-qPCR em 51 amostras de tumor primário, sendo 28 tumores primários linfonodo negativo, 23 tumores primários linfonodo positivo e 11 metástases axilares correspondentes. A expressão diferencial para os genes analisados não foi observada quando realizadas as comparações entre os grupos de tumores primários linfonodo positivo, linfonodo negativo e linfonodos correspondentes. Estes resultados sugerem que os genes ARD1A e NGX6 não tem poder preditivo no envolvimento de linfonodos em tumores mamários humanos.
\end{abstract}

Palavras-chave: Expressão gênica; Câncer de mama; Linfonodos.

\footnotetext{
${ }^{1}$ Graduanda em Biomedicina - Universidade do Vale do Paraíba - UNIVAP, Brasil. Email: elianeribeiro319@gmail.com.

${ }^{2}$ Graduanda em Biomedicina - Universidade do Vale do Paraíba - UNIVAP, Brasil. Email: raissa_monteiro_silva@uahoo.com.br.

${ }^{3}$ Médico Patologista - Centro de Medicina Diagnóstica / São José dos Campos, Brasil. Email: abaete@cipax.com.br.

4 Médico Mastologista - Hospital São Francisco de Assis, Departamento de Mastologia / Jacareí, Brasil. Email: drluismoraes@hotmail.com.

5 Professora, Doutora e Pesquisadora na Universidade do Vale do Paraíba - UNIVAP, Brasil. Email: rcanevari@univap.br.
} 